\title{
The Implementation Urgency of Conflict Management in Educational Organization for Industrial Revolution Era 4.0
}

\author{
Mukhamad Aang Kunaefi \\ Department of Educational Administration \\ Universitas Negeri Malang, Indonesia \\ aangkunaefi09@gmail.com
}

\author{
Imron Arifin \\ Department of Educational Administration \\ Universitas Negeri Malang, Indonesia \\ imron.arifin.fip@um.ac.id
}

\author{
Sultoni \\ Department of Educational Administration \\ Universitas Negeri Malang, Indonesia \\ sultoni.fip@um.ac.id
}

\begin{abstract}
Conflicts are often experienced in everyday life, do not know the time, place and conditions, including in the educational environment such as schools. Social interaction between education actors in schools often results in conflict, principals with teachers, teachers with students or with other parties in the educational environment. If the conflict that occurs cannot be managed properly, it certainly can disrupt the effectiveness and efficiency of the achievement of the organization resulting from unresolved conflicts. The ability to apply conflict management in the era of industrial revolution 4.0 is needed by a leader, including the principal who acts as a leader in school. Real demands in the era above are require school principals to master conflict management, so that it will have a positive impact on school achievement, specifically the quality of education that increases. Therefore, the author with all its shortcomings, wants to start discussing briefly and clearly about the importance of implementing conflict management in organizations in the industrial revolution era 4.0, can have a positive impact on leaders in dealing with conflicts, directed towards the implementation of conflict management, and maintain good social communication between education stakeholders. The author aims to study literature in the scope of the discussion that will be discussed in this paper.
\end{abstract}

Keywords: conflict management, educational organization, industrial revolution 4.0

\section{INTRODUCTION}

Organizations consist of various different components and are interdependent in the collaboration process to achieve certain goals. Differences found in organizations often lead to discrepancies that eventually lead to conflict. This is because basically when an organization occurs, then there are actually many possibilities for conflict.

Every organization that involves many people, in addition to having cooperation to achieve the goals of the organization is also not uncommon for differences of opinion, discrepancies and contradictions between them which lead to conflict. In any organization there are conflicts, both hidden and overt. Thus, conflict is reasonableness in an organization (Efendi, 2015), including in educational organizations.

Conflict is actually a natural thing in interaction and social interrelation between individuals or between groups. In the past, conflict was considered a symptom or phenomenon that was unnatural and had negative consequences, but now conflict is considered as a natural symptom that can have negative or positive consequences depending on how to manage it. That's why efforts are needed to manage conflict seriously so that the sustainability of an organization is not disrupted.

The study of the conflict causes or sources in the organization is intended as a basis for consideration the leadership of the organization, especially the leaders of educational institutions for controlling conflict. If various conflicts are managed well, then conflict can be used as a medium to criticize organizational performance. Thus, the existence of conflict does not need to be seen as a worrying event for the leadership, but precisely with the emergence of conflict, the organization becomes dynamic.

Overcoming and resolving a conflict is not a simple matter. The speed with which a conflict can be overcome depends on the willingness and openness of the disputing parties to resolve the conflict, the severity of the weight or level of the conflict and the ability to intervene (intervention) third parties who try to overcome the conflicts that arise. Conflict management is very influential for members of the organization. Organizational leaders are required to master conflict management so that emerging conflicts can have a positive impact on improving organizational quality.

Managers spend 20 percent of their work time dealing with conflict. In this case, the manager could be the first party directly involved in the conflict, and could also be a mediator or third party, whose role is nothing but resolving conflicts be-tween other parties that affect the organization and individuals involved in the organization they are handling (Wirawan, 2013).

It has become a demand for natural position and obligation as a manager to al-ways be faced with conflict. One the important point of the task of a manager in carrying out effective communication within the organization, is handling, ensuring that the meaning 
referred to in the instructions given will be the same as the meaning received by the recipient of the instruction and vice versa. He did in dealing with a conflict.

\section{LITERATURE REVIEW}

Based on the background above, the issues to be discussed in this paper are about conflict management, objectives, models and urgency in resolving various educational institution conflicts in the era of industrial revolution 4.0.

\section{Conflict Management}

Conflict is something that cannot be avoided in life. Even throughout life, humans are always confronted and struggled with conflict. Likewise, with organizational life. Members of the organization are always faced with conflict. New changes or innovations are very vulnerable to cause conflict (destructive), especially if it is not accompanied by an adequate understanding of developing ideas.

The etymological conflict originates from English, namely conflict, from Latin configure, which means each other is dropped or conflict occurs because there are parties who surprise each other in other words violence, innuendo, attitude, opinions, behavior, goals, and needs contrary (Rusdiana, 2016).

In terms of terminology, there are several definitions explained by experts, including: Afzalur Rahim states that conflict can be defined as an interactive state that manifests in attitude incompatibility, conflict, or difference with or between social entities such as individuals, groups, or organizations (Efendi, 2015). Whereas Wahjosumidjo (2002) defines conflict more simply that is, "All kinds of forms of relations between humans that contain opposites".

Organizational conflict is a discrepancy between two or more members or groups of organizations that arise because of the fact, must share limited resources or work activities and / or because of the fact that they have different status, goals, values, or perceptions (Rusdiana, 2016).

Substantive conflict is a dispute related to group goals, allocation of resources in an organization, distribution of policies and procedures, and division of job positions (Mulyasa, 2012). Conflict often creates opposition between the two parties, up to the stage that shows the parties involved look at each other as a barrier and disruption the achievement of their respective needs and goals.

Conflict can be interpreted as disagreement between two or more members of the organization or groups in the organization that arise because they have to use scarce resources together or carry out activities together and or because they have status, goals, values and different perceptions. Organizations who experience disagreement usually try to explain the problem from their point of view.

Each group in an organization, where interactions occur with one another, have a tendency to arise in conflict. Conflict is very closely related to human feelings, including feelings of being ignored, underestimated, unappreciated, abandoned, and also feeling irritated by overwork. These feelings can be a trigger anger. This situation will affect someone in carrying out their activities directly, also can reduce the work productivity of the organization indirectly by making many deliberate and un-intentional mistakes.

Conflict can also be interpreted as disagreement between two or more members of the organization or groups within the organization that arise because they must use scarce resources together or carry out activities together or because they have status, goals, values and different perceptions. Members of organizations that experience disagreement usually try to explain their problems from their point of view. The attitude of mutual self-defense is at least between two groups, which have different goals and views, in an effort to achieve a goal so that they are in an opposition position, not cooperation. Conflicts lead to certain consequences or risks, be-sides sometimes there are positive effects. G.W. Allport, as quoted by Hanson, stat-ed that more and more social scholars explained that conflict itself is not a crime, but rather a phenomenon that has constructive or destructive influences depending on its management (Hanson, 2010).

According to Ross (1993) that conflict management is the steps taken by actors or third parties in order to direct disputes towards certain outcomes that may or may not produce an end in the form of conflict resolution and may or may not produce calm, positive, creative things, consensus, or aggressive. Conflict management can involve self-help, cooperation in solving problems (with or without the help of third parties) or decision making by third parties. An approach oriented to the process of conflict management refers to patterns of communication (including behavior) of actors and how they influence the interests and interpretations of conflict (Umam, 2012).

Conflict management is a process of making plans and controlling conditions that are inappropriate and occur between parties in conflict. It also means a process of planning, organizing, leading and controlling various business members in the organization and using all the resources of the organization to achieve a certain goal. Conflict management as a process of parties involved in a conflict or a third party developing a conflict strategy and applying it to control conflict in order to produce the desired resolution (Wirawan, 2013).

Conflict management is a series of actions and reactions between actors and outsiders in a conflict. Conflict management includes a process-oriented approach that directs the form of communication (including behavior) from the actors and outsiders and how they influence interests (interests) and interpretations. For out-side parties (outside the conflict) as a third party, what is needed is accurate information about the conflict situation. This is because effective communication among actors can occur if there is trust in third parties (Rusdiana, 2015).

Conflict management is the steps taken by the perpetrators or third parties in order to direct disputes towards certain results that may or may not result in resolution of conflict and calm, positive, creative and consensus. Conflict management is a series of actions and reactions between actors and outsiders in a conflict. In principle, conflicts that arise in the implementation of 
educational units are as natural and dominant. In addition, conflict is an organizational dynamic. Look at that organization without conflict means being silent, static, and not achieving the expected progress.

\section{The Purpose of Conflict Management}

The main purpose of conflict management is how to build and maintain cooperative cooperation with subordinates, colleagues, superiors and outsiders. Some forms of conflict management behavior such as bargaining, and integrative problem-solving, are approaches to dealing with conflicts involving a manager and other parties whose assistance is needed to achieve work goals.

Regarding conflict management, Fisher as quoted by Rusdiana (2015) us-es the term conflict transformation more generally in describing the situation and objectives as a whole, namely as: (1) conflict prevention aims to prevent violent conflicts; (2) conflict resolution aims to end violent behavior through peaceful agreement; (3) conflict management aims to limit and avoid violence by encouraging positive behavioral changes for the parties involved; (4) conflict resolution addresses the causes of conflict and seeks to build new and long-lasting relationships between conflicting groups; and (5) conflict transformation overcomes the wider sources of social and political conflict and tries to change the negative forces of war into positive social and political forces.

The stages above constitute a unity that must be done in managing conflict so that each stage will involve the previous stage, for example conflict management will include prevention and resolution of conflicts (Rusdiana, 2015).

\section{DISCUSSION}

\section{The Application of Conflict Management}

Efforts to handle conflict are very important to do, this is because each type of change in an organization tends to bring conflict. Institutional changes that occur, whether planned or not, not only have an impact on changes in structure and personnel, but also have an impact on the creation of personal and organizational relationships that have the potential to cause conflict. In addition, if the conflict is not handled properly and thoroughly, it will disrupt the balance of resources, and tense the relationship between the people involved.

Facing conflicts that are inevitable in an organization, the conflict that arises should be managed so that it can become a tool used by the organization in the process of adapting to the changes that occur. The leader of the organization must be able to take a position quickly, because if it is not immediately addressed it will cause the growth of the organization itself to stagnate.

To deal with conflict there are three stages in managing conflict, namely: (1) Planning conflict analysis. At this stage identification of conflicts that occur, to determine the source of the cause and the parties involved in the conflict. If the conflict is already in an open stage, it can be easily recognized, but if it is still in the potential stage (hidden) it needs to be given a stimulus that will become open and can be known; (2) Conflict evaluation. At this stage an evaluation is carried out; and (3) Whether the conflict is nearing a broken point, so it needs to be muted so as not to cause negative impacts. Or the conflict still exists around a critical point that actually has a positive impact. Or even just in a hidden stage, so it needs to be given a stimulus to approach the critical point and have a positive impact.

Solve conflicts, at this stage the principal takes action to deal with the conflict, including providing stimulus if indeed the conflict is still in a hidden stage and needs to be opened. Conflict is something that cannot be avoided in life. Even throughout life, humans are always confronted and struggling with conflict. Like-wise with organizational life. Members of the organization are always faced with conflict. New changes or innovations are very vulnerable to cause conflict (destructive), especially if it is not accompanied by an adequate understanding of developing ideas.

There are three perspectives on conflicts that occur in organizations, namely the traditional flow, behavioral flow, and interactional flow: (1) Traditional flow states that conflict is seen as something bad, not profitable, and always causes harm in the organization. Therefore, conflict must be avoided and prevented by finding its source and being overcome; (2) Behavioral flow views conflict as something natural, naturally occurring in organizations, because without being created, conflict must occur within the organization. On that basis, conflict is not always detrimental, but can also be beneficial if managed properly; (3) The flow of interaction that views conflict in an organization should be created (stimulated). This view is motivated by the concept that "an organization that is calm, harmonious, full of peace, the condition will become static, stagnate (stagnation) and not innovative. The con-sequence is that organizations cannot compete for progress (Soetopo, 2016).

Conflicts can be beneficial and can also be detrimental to the life of the organization in real terms. A favorable conflict is called functional conflict, while an adverse conflict is called a dysfunctional conflict. Conflict will be functional or useful if the two parties in conflict encourage each other to fix each other's mistakes, rather than dropping each other, blocking each other's achievement of goals, and mutual importance to their own interests. Because this is what can cause conflict to be dysfunctional or harmful (Triatna, 2015).

The method often used to deal with conflict is first by reducing conflict; second by resolving conflicts. For the method of conflict reduction, one way that is often effective to do, is to cool the problem first (coolingdown). However, this kind of method has not actually touched the real problem. Another way is to make a "com-mon enemy", so that the members in the group unite to face the "enemy". This kind of method actually only diverts the attention of group members who are experiencing conflict. The second method is the method of conflict resolution. The method is taken to dominate or suppress, compromise and solve problems integrative.

\section{The Benefits of Conflict Management}

Conflict is something that cannot be avoided and always exists in social life. Some case is also happening in an organization, where individuals are often faced with 
conflict. The existence of changes or innovations can be a conflict, especially if it is not accompanied by a good understanding of new ideas. Not all conflicts harm the organization, conflicts that are well organized and controlled can benefit the organization as a whole. To organize conflict within the organization, it requires openness, patience and awareness of all parties involved as well as those who have an interest in conflicts that occur within the organization (Subandi, 2016).

There are also several companies that deliberately engineered to cause conflict. This is done because of the companies the conflict management strategy can actually boost employee motivation in competing, but in some conditions, the conflict causes the company and its employees difficult to develop professionally. Inevitably management of conflict will greatly affect individuals in an organization. Therefore, leaders in organizations must have adequate conflict management capabilities, so that conflicts that arise will have a positive impact on the organization. Questions that might arise in our minds, why should organizations develop conflict management? Conflict management within organizations will enable the organization to. First, System Evaluation, Companies and educational institutions cannot evaluate the effectiveness of the system if there is no conflict within the organization. Constructive conflicts will help companies or educational institutions in identifying whether the system that has been carried out is effective improvement. Second, developing competencies, Proper handling of conflict management supported by strategies and systems will help organizations develop their competencies, especially in terms of non-technical competencies. Conflict management can improve organizational skills in handling internal conflicts so that the organization becomes stronger.

\section{Conflict Management in Educational Organizations}

Conflict can be interpreted as a condition where a person is faced with conflicting motives, beliefs, values and goals. Conflicts can be experienced by anyone and anywhere, including by the community at school. Students, teachers, or even the principal at certain times are very likely to be faced with conflict.

In education, it takes a school principal who is able to resolve conflicts that occur in his institution. Educational conflict management can be interpreted as a step taken by the principal to manage the conflict that occurs, so that educational goals can be realized optimally. Conflicts experienced by individuals in schools can come in various forms, can be in the form of individuals with individuals, individuals with groups or groups with groups. For example, a teacher faces a teacher, a teacher is faced with a group of teachers, a group of certain teachers is faced with a group of other teachers, and the like. Conflicts that occur between them can be closed, open or even confrontational.

Factors that can lead to conflict in an educational organization include: a variety of scarce resources found in schools, differences in goals between teacher's principals, interdependence in carrying out work, differences in values or perceptions. In addition, for the reasons above, there are also other causes that might cause conflict in education such as one's style of work, organizational ambiguity (especially private institutions) and non-directed communication problems.

If the conflict that occurs in the school is not managed and is destructive, then besides being able to disrupt the health and quality of one's life, it can also interfere with the achievement of the effectiveness and efficiency of education in the school as a whole. If the conflict leads to destructive conditions, then this have an impact on reducing work effectiveness in organizations, both individually and in groups. Usually each group tries to do in the rejection form, resistance to change, apathy, indifference, maybe even a destructive burst of emotion, in the form of a demonstration.

In addition, the function of management of conflict education is to avoid conflict, accommodate (giving other people the opportunity to set up problem solving strategies, especially if the issue is important to others), competition, compromise or negotiation, problem solving or collaboration. The leadership of the education unit must have the strength and authority as the leader of education. They must be able to utilize the strength that can be able to utilize the authority that is to direct the attitudes and behavior of subordinates. Thus, the existing conflict must be coordinated so that the dynamics that occur can be something positive to produce change while supporting the development and achievement of educational goals.

Conflicts in schools can have positive and negative impacts, and can encourage innovation, creativity and adaptation. Schools that do not develop may be caused by principals who are too easily satisfied with their achievements, so they are less sensitive to changes in the environment, and there are no differences of opinion or new ideas. Although conflict often benefits the progress of schools, it can reduce performance, lead to dissatisfaction, increase tension and stress (Mulyasa, 2012).

Conflict management models are important to implement in dealing with conflicts in schools. Conflict handling models leading are: (1) competition, (2) avoidance, (3) collaboration, (4) compromise, and (5) accommodation. This model is described as a model that focuses on power, is probably the right approach.

The second model is the avoidance model. This model is a model that is not assertive and non-cooperative where a person is involved in work not only for his personal interests or for disturbing other groups. This is the best approach because it is accordance with the principle. The collaboration approach is the opposite of the avoidance model, is characterized by assertiveness and cooperation. This model focuses on satisfying the needs of both parties involved. In this case the two groups agreed to cooperate.

A collaborative approach to conflict management, we argue, is likely to strengthen the level of trust and cooperation between leaders and administrators. Collaboration is probably a useful strategy especially for conflict resolution involving stake-holders with different powers. The compromise model is a middle-way to implicate a conflict management, this model implicates between assertiveness and assertiveness and becomes 
effective if both parties are willing to sacrifice to reach an agreement. The latter is an accommodation model that is characterized by uncertainty and cooperatively and this model is the opposite of the competition model. In this model, individuals defeat their interests so that they can accommodate the opponent's needs (Ghaffar, 2011).

\section{Management Conflict in Industrial Revolution 4.0}

In the era of industrial revolution 4.0 challenges are increasingly apparent and have an impact on education. The era of all needs is oriented towards sophisticated technology. The implementation of the era's development now needs to be adjusted by the principal as the leader in the school. According to Lee and Wong (2019) the era of industrial revolution 4.0 familiarizes people to use technology in all their activities. If this is not faced seriously, it will have an impact on the gaps that can lead to conflict. Implementation of conflict management in the era of industrial revolution 4.0, it must be realized that the use of technology such as communication via social media is very easy and effective, but the range of conflicts will result from communication. The role of a leader is needed in order to be able to act effectively in resolving conflict problems that occur due to social media between teachers and teachers, principals with teachers, and teachers with students.

\section{CONCLUSION}

Conflict is all kinds of forms of relations between humans that contain opposing traits. Whereas conflict management is a step taken by actors or third parties in order to direct disputes towards certain results which may or may not result in resolution of conflict and calm, positive, creative and consensus.

The main purpose of conflict management is to build and maintain cooperative cooperation with subordinates, colleagues, superiors and outsiders. Conflict management models are important to implement in dealing with conflicts in schools. The leading models for handling conflict are: competition, avoidance, collaboration, compromise and accommodation.

Conflicts in schools can have positive and negative impacts, and can encourage innovation, creativity and adaptation depending on the extent of the application of conflict management in dealing with conflicts. For this reason, the implementation of conflict management is very urgent to be applied in educational organizations in the era of industrial revolution 4.0. Based on this fact, principals must have adequate conflict management capabilities, so that conflicts that arise in schools will actually have a positive impact on the progress of the school in facing the challenges of the development era.

\section{REFERENCES}

[1] Efendi, Nur. (2015). Islamic Educational Leadership. Yogyakarta: Kalimedia.

[2] Fahmi, Irham. (2016). Perilaku Organisasi Teori, Aplikasi, dan Kasus. Bandung: Alfabeta.

[3] Ghaffar, Abdul. (2011). Conflict in Schools: Its Causes \& Management Strategis. Journal of Managerial Sciences Volume III, number II.

[4] Hanson, Mark. (2010). Educational Administration and Organizational Behavior. Boston: Allyn and Bacon.

[5] Lee, K., \& Wong, C.Y. 2019. Is the Fourth Industrial Revolution a Window of Opportunity for Upgrading or Reinforcing the Middle-Income Trap? Asian Model of Development in Southeast Asia: Journal of Economic Policy Reform, 23, 1-18.

[6] Mulyasa. (2012). Manajemen \& Kepemimpinan Kepala Sekolah. Jakarta: Bumi Aksara.

[7] Ross, Marc oward Ross. (1993). The Management Conflict: Interpretation and In-terest in comparative perspective. Yale University Press.

[8] Rusdiana. (2015). Manajemen Konflik. Bandung: Pustaka Setia.

[9] Rusdiana. (2016). Pengembangan Organisasi Lembaga Pendidikan. Bandung: Pustaka Setia.

[10] Soetopo, Hendyat. (2016). Perilaku Organisasi Teori dan Praktik di Bidang Pen-didikan. Bandung: Rosda.

[11] Subandi, Bambang. (2016). Manajemen Organisasi dalam Hadis Nabi. Yogyakar-ta: INDeS.

[12] Triatna, Cepi. (2015). Perilaku Organisasi dalam Pendidikan. Bandung: Rosda.

[13] Umam, Khaerul. (2012). Perilaku Organisasi. Bandung: Pustaka Setia.

[14] Wahjosumidjo. (2002). Kepemimpinan Kepala Sekolah Tinjauan Teoritik dan Permasalahannya. Jakarta: PT. Raja Grafindo Persada.

[15] Wirawan. (2013). Konflik dan Manajemen Konflik Teori, Aplikasi, dan Penelitian. Jakarta: Salemba Humanika. 